\title{
O TREINAMENTO COMO TRAMPOLIM - ENTREVISTA COM CARLOS SIMIONI
}

\author{
Marcelo Teixeira ${ }^{2}$ \\ Mestrando em Artes Cênicas pela Universidade Federal de Ouro Preto \\ marcelomarquesteixeira@gmail.com \\ Cláudia Müller Sachs \\ Professora adjunta do Departamento de Arte Dramática da UFRGS. \\ Doutora em Teatro pela Universidade do Estado de Santa Catarina \\ Atriz, diretora e preparadora corporal. \\ claudiasachs@terra.com.br
}

De maneira informal e descontraída, Carlos Simioni compartilha sua experiência e seu profundo conhecimento da arte do ator num bate-papo que nos aproxima desse importante momento da história do teatro e da atuação no Brasil. Simioni nos conta como iniciou o treinamento e a criação do LUME nos anos 80 e como todas essas técnicas vêm evoluindo até hoje. Visita sua experiência com Luis Otávio Burnier, com a Mímesis Corpórea, com o Clown e com o seu treinamento pessoal, incluindo técnicas como a Dança dos Ventos, o Samurai, e outras mais recentes como o Portal e as Camadas. Esta entrevista foi realizada e transcrita por Marcelo Teixeira, em 29/08/2016 em Parati-RJ, a pedido de Cláudia Sachs, que preparou uma série de perguntas para organizar e direcionar a conversa com Simioni.

\section{Palavras-chave}

Treinamento do Ator. LUME. Simioni. Antropologia Teatral.
In an informal and relaxed way, Carlos Simioni shares his experience and his deep knowledge of the actor's art in a chat that brings us closer to this important moment in the history of theater and acting in Brazil. In this interview, Simioni tells us how he started the training and the creation of LUME in the 80's and how all these techniques have evolved to this day. He visits his experience with Luis Otavio Burnier, Corporeal Mismesis, Clown and his personal training, including techniques such as Wind Dance, Samurai, and more recent ones such as Portal and Layers. This interview was performed and transcribed by Marcelo Teixeira on the 29th of August 2016 at the request of Cláudia Sachs, who prepared a series of questions to organize and direct the conversation with Simioni.

Keywords

Actor's Training. LUME. Simioni. Theater Antropology.

\footnotetext{
1 Carlos Simioni: ator, diretor, professor e membro fundador do LUME Teatro, Campinas - SP.

2 Marcelo Teixeira é um dos integrantes do projeto A.P.A: Ateliê de Pesquisa do Ator. Fundado em março de 2014, este projeto é uma iniciativa do Centro Cultural Sesc Paraty-RJ e é executado em parceria com os atores-pesquisadores Stéphane Brodt (ator e diretor do Amok Teatro) e Carlos Simioni. O A.P.A. possui um caráter formativo com ênfase na pesquisa e na criação de uma metodologia própria de trabalho voltado para o ator. Criado e realizado em módulos contínuos, o projeto dialoga com outros núcleos de pesquisa, descentralizando conhecimento e iniciando um polo internacional de intercâmbios em Paraty. O projeto funciona através de encontros mensais que duram, aproximadamente, 18 horas de investigação prática durante um fim de semana.
} 
Marcelo Teixeira - Você poderia nos contar sobre o inicio das práticas relacionadas à Antropologia Teatral de Eugênio Barba ? Como você se aproximou? O que buscava naquela época?

Carlos Simioni - Na realidade, foi o Luís Otávio Burnier que conheceu Eugenio Barba na Europa, em 1983, e teve contato com a Antropologia Teatral e tudo mais. Ele voltou para o Brasil e nós criamos o LUME. Eu não sabia que existia o Barba, eu não sabia de nada, e ele só me falou que tinha um grupo na Dinamarca que trabalhava muito o teatro físico, e, sobretudo, a Antropologia Teatral. Como na época Luís Otávio queria criar um núcleo de pesquisa dentro da Universidade, a Antropologia Teatral para a Universidade era um grande gancho. Criar um núcleo de pesquisa da arte do ator baseado na Antropologia Teatral. Então, foi muito importante! Chegar para uma banca de doutores para convencer de que existe, sim, trabaIho de pesquisa na arte do ator, por exemplo, se você estuda o Kathakali, se você estuda as manifestações teatrais, o homem em situação de representação, que é a Antropologia Teatral. Nesse sentido, foi um grande aliado para a gente começar o LUME, um grande aliado da Antropologia Teatral. Assim, trouxemos o Odin Teatret e o Eugênio Barba pela primeira vez ao Brasil em 1987, justamente, que conseguimos através da UNICAMP, por ser a Antropologia Teatral. Então foi um projeto aprovado pelas instâncias superiores, justamente, por ser pela primeira vez ser apresentado para os atores brasileiros esta metodologia que até então era muito fresco em nossa cabeça, para mim, principalmente, pela primeira vez. Só que quando Eugênio apareceu, o Odin apareceu, nós do LUME, que era só eu e Burnier, tínhamos um treinamento, que é o treinamento energético trazido do Decroux, do Yves Lebreton e do Grotowski. Luis Otávio tinha trabalhado com a Rena Mireka, atriz do Grotowski, e ela ensinou, transmitiu, justamente o treinamento energético.

MT - Você poderia nos contar sobre aquele momento histórico, no final dos anos 80 ? Como eram as expressões teatrais por onde você transitava em São Paulo e no Brasil?

CS - Na realidade eu não posso (risos), porque eu sou um ator de Curitiba e fiquei até 1984 em Curitiba, mas eu era jovem, 23 ou 24 anos, e Curitiba era muito fechada, era o teatro curitibano, eu não viajava para isso, para nada, e só fazia escola de Teatro. Então, eu via só as coisas de lá. Quando eu cheguei a Campinas para criar o LUME junto com Burnier em Barão Geraldo, que era isolado, a gente trabalhava oito, dez horas por dia! Não existia muito teatro em Campinas e o Burnier tinha uma ideia, que eu aceitei, de a gente mergulhar numa pesquisa que nós não sabíamos no que ia dar! Mas era dedicação exclusiva, ele pedia até que a gente não visse nada para não se influenciar, que não assistisse nada. Também porque tinha que ir para São Paulo, era difícil na época, eu não tinha dinheiro e tudo mais, mas a ideia era de se isolar.

\section{MT - E no resto do Brasil?}

CS - Então, eu não posso dizer como que era o final dos anos 80 em São Paulo, no resto do Brasil. A gente viajava, começamos a viajar. Para dizer bem a verdade, quando começou o LUME, eu acho que apenas cinco anos depois, pois ficamos realmente mergulhados. Não éramos conhecidos, nada! A primeira chamada que nos fizeram para dar um curso 
foi em Canela, no Rio Grande do Sul, e foi lá que toda galera de Porto Alegre teve acesso ao trabalho que nós estávamos desenvolvendo no LUME. O primeiro grupo que eu vi foi o "Ói nóis aqui traveiz", com o espetáculo Antígona. Eram três horas de espetáculo, lindo, maravilhoso, impressionante, eu e o Burnier ficamos embasbacados. O Burnier tinha uma coisa que ele não era fechado. Por exemplo, ele veio para o Brasil para criar o LUME, veio com o treinamento do Grotowski, o treinamento energético. Aí, depois, o Barba veio com a Antropologia Teatral, e o Burnier estava muito interessado em pesquisar a cultura popular brasileira. Então ele pegou a Antropologia Teatral como referência. Até o próprio Barba, quando veio para cá em 1987, eles foram no terreiro do candomblé justamente para ver as danças dos orixás para entendê-las. Fomos até Olímpia, que é a cidade que tem o Festival de Folclore, para ver a Congada, para conhecer, para ver se tinha alguma semelhança, para ver se a gente poderia também aplicar a Antropologia Teatral com a cultura brasileira neste sentido. Então a Antropologia e o Barba nos ajudaram muito! Porém, o Burnier não era fechado, você entende? Ele se encantou com o trabalho do "Ói nóis aqui traveiz", e fizemos um intercâmbio, neste sentido. Então, ele não era algo fechado, tipo: "vai ser este treinamento" ou "vai ser só a Antropologia Teatral".

MT - Você estava na graduação naquela época?

CS - Não, nem fiz graduação. Eu não entendia nada, eu era tipo assim, "Maria vai com as outras". (risos) O Burnier dizia "vamos tentar isso", eu tentava. Eu gostava, mas não sabia da ligação... Burnier não me deixou ler nenhum livro. Do Grotowski, ele só me deu depois de quatro anos, e me deu o do Eugênio Barba, então me inteirei disso. Eu era um discípulo completamente entregue nas mãos dele. Então, eu não posso dizer como era o teatro dos anos 80 . Mas o que mais me impressiona é que justamente nestes anos 80, que veio o Odin, o Teatro Tascabile di Bergamo e o Potlach da Itália. Os dois últimos da Itália, que também têm uma ligação muito forte com o treinamento com o treinamento do Odin, grupos já consolidados, já com quase 40 ou 47 anos. Mas na época que eles vieram para o Brasil, no Rio de Janeiro, principalmente, foram muito bem aceitos pelos jovens atores, o "treinamento de ator". De você treinar teu corpo, treinar tua voz, porque até então, naquela época, salvo algumas exceções - porque eu não posso dizer que conhecia tudo né?- , não existia um treinamento para o ator! Existia dança, existia esgrima, existia a capoeira, mas especificamente para o ator, não existia. Então, foi realmente uma grande novidade que atraiu muitos jovens, muitos! Eu lembro que muitos jovens do Rio de Janeiro foram para Itália com o Potlach e com o Tascabile, muitos jovens. Até hoje tem alguns que estão lá! Encontrei, esses dias, na Itália, um brasileiro que estava lá desde 1987! Então, teve essa efervescência do treinamento, isso era novo, não existia.

MT - Como foi a transição entre o treinamento e a criação do LUME?

CS - Na realidade, a diferença básica, que achei fantástica do Burnier, é que ele não estava interessado em criar técnica, ou só técnica, ou treinamento. Ele queria, principalmente, tentar encontrar dentro no trabalho do ator algo que fosse vivo, que permanecesse vivo, apesar do treinamento. Lembro que o primeiro treinamento do LUME era a Mímica Corporal 
Dramática do Decroux, porque o Burnier trabalhou com ele por 8 anos. Ele tentou me passar a Mímica, mas não deu certo para mim porque não me afinei com essa técnica precisa... precisa, sabe..."TAC”! E foi muito bom, porque daí a gente tentou encontrar uma maneira de fazer com que eu encontrasse um treinamento que me deixasse vivo, alegre, satisfeito e que eu produzisse uma qualidade de presença e de energia. $\mathrm{E}$ ali, quando eu conseguia isso, Burnier canalizava para a forma, às vezes, entende? Canalizava para a forma. Isso fez com que a técnica do LUME nascesse assim, entre a técnica e o estado de ser do ator. As duas coisas nunca eram separadas... nunca eram separadas...

MT - Então a intervenção dele aparecia com mais frequência só quando o "estado" já estava implantado..

CS - Na realidade ele era tão perspicaz! Ele sabia que tinha que dar uma forma a essa explosão de energia que existia no trabalho que a gente estava inventando. Mas ele não me falava: "Simioni, tem que dar forma"! Lembrese que eu falei para você que eu era um garoto, né? Não entendia de nada. Ele conduzia o trabalho de uma forma que toda expressão minha, do treinamento, se transformasse em uma forma que a gente começou a chamar de "Matriz". São "Matrizes" que vêm de uma qualidade de emoção ou de energia que se desemboca numa expressão com uma forma, mas não que eu quisesse fazer forma. Ele sabia, ele me puxava para isso. Então começou a ser um treinamento muito vivo. Tanto é que desembocou no primeiro espetáculo do LUME "Kelbilin - O cão da Divindade", que é oriundo de todas as matrizes que a gente encontrou por três anos, que iam saindo e ele ia corpo- rificando e arrumando em formas e tudo mais. Então, quando você pergunta sobre a transição do treinamento e a criação do LUME... Aí, no caso, a criação começou no treinamento. Era no treinamento puro. Ai, logo vou responder uma pergunta do clown aqui! Como que entrou o clown? Porque entrou o clown? Porque justamente o Burnier era muito inquieto em relação ao trabalho do ator. Ele não queria seguir os outros, você entende? Ele queria beber dos outros. O clown vem de Rique' ${ }^{1}$. Ele era apaixonado por palhaço! Apaixonado, apaixonado, apaixonado. E conheceu o Burnier, que o convidou ele para fazer parte do LUME. E ele tinha uma coisa de dizer assim" cada ator que vai vir trabalhar no LUME vem com um desejo e nós vamos realizar esse desejo". E o do Rique era de ser clown. Só que não posso abandonar tudo e começar outra coisa. O Simioni, coitado, que já está aqui há três anos né?... etc. Então, ele disse assim: "vamos estudar o palhaço. O que nós estamos estudando? Estamos estudando a organicidade do ator, a vida do ator, os elementos do ator através do corpo. Como que é um clown nisso? Como que é um clown? "Daí é que começamos a desenvolver. Ele já tinha feito oficina de clown com Philippe Gaulier, ficou apaixonado, e resolveu já iniciar a mim e ao Rique. Eu não tinha nem ideia do que era clown. Não tinha menor ideia! Ele resolveu fazer um retiro de 11 dias. "Quero pegar 10 ou 12 atores e vou ficar numa fazenda 10 ou 12 dias explorando o trabalho do ator e o clown para ver como encontrar dentro da nossa maneira de trabalhar uma iniciação do clown". Então o básico era: tínhamos todo o trabalho corporal, já desenvolvido durante três anos com o próprio treinamento energético, e

1 Ricardo Pucetti, ator do LUME. 
a própria "Dança Pessoal". Sim, isso foi uma coisa nova que o Burnier fez: tudo aquilo que eu fazia, e que se transformava em Matriz, a gente chamava de "Dança Pessoal", que cada ator teria que encontrar a dele.

MT - Mas também não está muito distante do universo do clown, né? Assim, vejo que há uma relação entre esta busca através dos treinamentos, com a Dança Pessoal e o palhaço...

CS - Foi onde bateu na lata! Quando nós começamos a fazer o clown e que Burnier começava a ver que o clown, o palhaço, tem essa sensibilidade, e que tem muitas coisas dele que é escondida, que ele não mostra a sociedade...Tanto a beleza, a pureza, quanto a maldade, né? A maldade, tipo assim: "eu não vou fazer maldade com você, porque, eu estou te odiando, mas eu não posso socialmente..."

MT - ...a sociedade não permite...

CS - Exatamente. E isso foi sendo revelado no trabalho do clown, e é justamente através dessa abertura que o treinamento dá para o ator, o treinamento expande, faz você vencer barreiras, e quando o ator chega e ultrapassa essas barreiras, ele está muito vulnerável e muito aberto a coisas novas... ali plantar a semente da ternura! Nem plantar, trazer à tona a fragilidade que já está no próprio ator, ali era um campo maleável, um campo fértil. Daí o clown surgiu! Tanto é que os clowns do LUME, os primeiros, não tinham palavras. Tanto que temos espetáculos até hoje que eu e o Rique não temos uma palavra. Por quê? Justamente, essa junção de pesquisa que o Burnier queria fazer... o clown, a sua expressão máxima da beleza de ser tudo isso, um clown no corpo.
MT - O interessante, pelo o que vejo, é que o clown não surge como uma ruptura do que já vinha sendo realizado, só para satisfazer uma suposta idealização estética, mas sim, por uma necessidade de aprofundar o treinamento que já vinha sendo feito, estou certo?

CS - Exato! E nós não tínhamos nenhuma regra para o clown. A única que eu lembro, foi quando o Burnier passou um filme do "Gordo e do Magro" só para a gente ter uma noção do que era Branco e Augusto e o tempo do clown. O tempo, sabe? O clown não rebate. Ele recebe a situação, recebe a merda ou o que for, ele engole para depois não sair só com inteligência. É como o ser.

MT - Percebo, então, que vocês sempre procuraram um determinado entendimento através da experiência prática ao invés de partir dos livros ou de conceitos teóricos. Certo?

CS - Sim, exatamente. Por exemplo, o Burnier me proibiu de ler o livro do Grotowski. E eu fiquei três anos trabalhando o treinamento energético sem saber o que era. Mas três anos! Aí ele falou: "Toma, agora lê". Cara, quando eu comecei a ler o "teatro pobre", eu juro para você, a cada frase do Grotowski parecia que ele estava falando do meu trabalho! Então o LUME tem essa característica. O LUME vai lá para criar! Por exemplo: como nasceu a "Mímesis Corpórea"? Do trabalho do Burnier, quando ele não morava no Brasil, ele teve que morar no Equador e lá ele via aqueles meninos de rua. Ele ficou encantado de ver a beleza dos meninos de rua, a gestualidade deles. Ele começou a seguir esses meninos para ver o que eles tinham, o que era o gesto deles e tudo mais. Foi aí que ele fez até o espetáculo chamado "Macário", que é um solo, só na Mímesis desses garotos de Quito. Aí quando ele 
voltou para o Brasil, passou um tempão, teve o treinamento energético, teve a Dança Pessoal, depois teve o clown. Porque ele pensava o seguinte: o treinamento energético, o extrapolar limites, dá para o ator essa enorme presença, porém tudo dilatado, é quase que um monstro. $\mathrm{O}$ ator fica um monstro! Aí ele percebeu que a ternura e a fragilidade do clown veio colocar um caldinho ali...

MT - ...acalmar o leão...

CS - ... acalmar o leão, exatamente, acalmar o leão. Só que o trabalho do Burnier era de você para fora, você entende? Não ia Ihe dar nada, nada, nada, de você para fora. Então tudo que saiu de mim era o Simione. "Kelbilin", por exemplo, é o Simioni. As minhas entranhas que vieram para fora. O clown também é o Simioni, e no caso o Rique também. Minha fragilidade, minha vergonha, minha timidez, mas minha! $A$ Mímesis chega porque o Burnier disse assim, "esses meninos" (porque nós éramos uns meninos) "esses meninos precisam agora ter contato com o fora". Porque até então era tudo de dentro para fora. Agora é o fora para dentro. Aí que ele relacionou a Mímesis com aqueles meninos que ele imitou, então ele começou a pesquisar. Então, vamos tentar ver se a gente encontra um método de como você imita as pessoas de fora! Ele começou com os animais, para depois pegar as pessoas. Aí que era lindo, você entende? Porque a gente pegava a gestualidade das outras pessoas, punha no nosso corpo mas ficava altamente mecânico, feio e caricaturado. Aí, o que ele fazia? Você, que está completamente aceso, com teu treinamento, com a tua ternura do clown, com a violência de tua Dança Pessoal, vamos assim dizer, coloca esse outro ser junto. Assim, porque esse outro ser tem que se diluir neste meu ser.
MT - Achar equivalências?

CS - Exatamente. Eu não posso ser o outro. O outro tem a história dele, estou pegando a gestualidade dele e tudo mais. Eu tenho que fazer com que ela se infiltre em mim e que daí eu...

MT - Então é por isso que não é uma imitação. É uma recriação do vivo. Que parte de sua vida...

CS - Isso! Não é imitação só por imitar. Também o Burnier dizia: "você só vai imitar uma pessoa se, quando você for conversar com ela e bater algo em você daquela pessoa, dos sentimentos". Tipo assim: "Nossa, essa pessoa tem algo que eu tenho também dentro de mim", entende?

MT - E esse "bater" é subjetivo mesmo?

CS - Subjetivo. Não tem explicação. É um sentimento ali, né? Estou conversando com uma pessoa, um velhinho, por exemplo, ...hummm "não gostei". Se você não gostou da pessoa, nem tente! Tem que ter algo a ver contigo, que te toca. Para você pegar justamente isto, esta coisa que te toca, para desenvolver a Mímesis.

MT - Com a entrada e a permanência de outros atores-pesquisadores no LUME, houve alguma alteração na pesquisa que já vinha sendo desenvolvida pelo Burnier?

CS - Sim. Isso que eu vinha dizendo. O Burnier veio com esta lógica. Ele começou comigo, era um treinamento. Aí veio o Rique, entrou clown. Aí veio a Mímesis e entrou a Mímesis. E foi crescendo, ia transformando o treinamento. Ia transformando, transformando... Mas esses atores que estão até hoje, no momento que eles entraram, não. Porque, justamente, eles entraram aprendendo tudo que já tinha no LUME. Eram nove anos de LUME, já. Tanto 
eu, Rique e Burnier, nove anos nós três. Então, é tudo que o LUME tinha quando eles aprenderam. Porém, tiveram dois fatores: um que o Burnier morreu logo em seguida, não deu muito tempo, e então ele morreu. Trabalhou só um ano e meio com eles. E o outro é que daí sim, outras pessoas chegaram.

MT - Mas a questão que eu coloco é a seguinte: da mesma forma que o Rique trouxe a necessidade do clown, os outros também trouxeram com eles algum outro desejo de pesquisas?

CS - Esses novos atores entram no LUME dessa maneira: eles eram alunos do departamento de artes cênicas da UNICAMP, alunos do Burnier. Só que o Burnier dava mímica, na universidade, mímica do Decroux, e introdução ao treinamento energético para o ator. No $4^{\circ}$ ano tinha que ter uma montagem, eles convidaram Burnier para fazê-la. Ele só aceitou se eles aceitassem que o Rique e eu também participassem. Então iríamos ficar um ano, de janeiro a dezembro. Era a primeira vez que o LUME (eu, Rique e Burnier) ia tentar aplicar tudo o que nós pesquisamos em nove anos, certo? Nós tínhamos um ano para aplicar para essas pessoas. Mas tinha que ter uma montagem no final. O treinamento foi maravilhoso. Todas as coisas! Esqueci de falar numa outra coisa da Iben ${ }^{2}$ também, que entra junto com o treinamento. Na realidade era tudo confluência, entende? Esses atores queriam montar algo sobre a lenda. As lendas brasileiras. Eles que davam as rédeas, os temas e tudo mais. Aí o Burnier falou o seguinte: "Bom, então no lugar (eram 11 atores) de vocês pegarem pelos livros as histórias e as lendas, vão lá onde estão as lendas vivas." Aí ele deu uma pequena intro-

2 Iben Nagel Rasmussen, atriz do Odin Teatret. dução para esses atores da Mímesis, que ele estava elaborando ainda, estava em fase de aplicação, para ver se funcionava. Eles foram todos preparados e foram para a Amazônia. Foram lá para o Rio Grande do Norte, depois para o norte do Mato Grosso, foi uma viagem que eles foram buscar, e eles vieram com muito material, de imitações de canções, de lendas e de histórias, e então o espetáculo foi montado em cima disso. Esses alunos adoraram a Mímesis, que justamente estava naquele ponto que eu falei: como que você coloca a outra pessoa, o imitado, para dentro do teu caldeirão e transforma numa terceira coisa, mas que é você mesmo, né? E eles continuaram. Então a Raquel e o Jesser ${ }^{3}$ adoraram isso daqui. $E$ tudo ótimo! Porém, o Burnier morreu. Logo em seguida ele morreu, né? E que foi ótimo (risos), não porque ele morreu. Foi ótimo de ter esses atores novos que vinham com essa carga, essa vontade também de desenvolver uma linha de pesquisa que era a Mímesis. E é lógico que o treinamento vai mudando, tudo vai mudando. Porque daí você tem encontrar maneiras para que essa Mímesis funcione, que ela seja viável, era tudo muito intrincado. Não fazia Mímesis só pela Mímesis, querendo imitar. Não, mas o quê o treinamento energético, esse corpo que eu tenho hoje, que já treinei há dez anos, o que esse corpo me deu? Não que eu precise repetir esse treinamento... o treinamento em si ele só serve para uma coisa, para trampolim, para algo mais. Se você ficar encerrado, preso no treinamento, realmente é terrível, não leva a nada, leva ao mecanicismo, leva a dores. Quando ele não avança, quando não sai dele mesmo, ele se torna um exercício físico e pronto. Eu vou lá fazer todo dia mas ele não 
me acorda mais, ele amortece! Se você ficar só no treinamento ele amortece! Esqueci de falar desse periódo aí: quando Eugênio veio para o Brasil eu vi, o bobinho, os atores do Odin Teatret, a presença dos atores, a dilatação da presença dos atores. A beleza de ver aquelas pessoas em cena. A dilatação, a presença, tudo o que me tocava. Eu fiquei encantado em ver aquilo alí! Por sorte uma das atrizes, a Iben, estava naquele momento criando um grupo de atores com quem ela queria trabalhar por mais tempo. Ela falava o seguinte: "eu já tenho 25 anos de Odin (ou tinha naquela época), a gente viaja o mundo todo, eu vou lá e dou workshop de 5 dias e nunca mais vejo a pessoa." Então ela tinha resolvido naquela época não dar mais workshop e escolher dez atores, um de cada parte do mundo, para ela fazer um encontro anual para que ela seguisse os atores. E eu fui um dos escolhidos. Que sorte! O LUME começou em 1985, isso foi em 89 , quando eu fui para a Dinamarca com a "Ponte dos Ventos".

MT - Nesta época o Burnier já tinha falecido?

CS - Não, não.

MT - A montagem com os meninos do UNICAMP já tinha acontecido?

CS - Não, não tinha.

MT - Então quando a montagem começou você já estava na "Ponte dos Ventos"...

CS - Já estava na "Ponte dos Ventos". E quando chego lá, onde eu chego? No "Odin Teatret", a grande referência do treinamento que eu já vinha fazendo há um bom tempo, mas que eu nunca tinha visto, porque era a gente que descobria, eu e o Burnier. A Iben, naquele momento, também não queria reproduzir o treinamento do Odin. Ela não queria reproduzir e passar para nós, mas sim "vamos inventar um treinamento". Claro que ela tinha bagagem do Odin, não ia começar do nada. Foi aí onde ela criou a Dança dos Ventos, você entende? A Dança dos Ventos não se enquadra só na exaustão. Claro que ela cansa, mas ela dá para o ator uma coisa fantástica que é um fluxo interno de você estar no ar e desenhar o seu corpo com as energias aéreas. De você ser pontual, de você dar para o ator o controle, no sentido de dizer "eu tenho que ter um passo, eu tenho que fazer uma respiração, eu tenho que me relacionar com os colegas, eu tenho a sala inteira para voar, eu tenho que atacar, eu tenho que defender, eu tenho que vencer meu cansaço", meu pensamento fica louco ali! A Iben dizia o seguinte: "não é você que pensa, é o corpo que pensa na Dança dos Ventos!" E você dá suas piruetas, entende? Então, nesse sentido, é fantástico para o ator, ele desenvolve uma perspicácia, a percepção do todo e de como ele controla o seu corpo, e como isso serve para qualquer outro tipo de trabalho depois, até para o clown, você entende? É por isso que muita gente confunde o treinamento: "treinamento é isso e ponto, e acabou." Nada, pelo contrário, ele só é um trampolim! Ele tem que ser aprendido, tem que ser construído certo, correto.

MT - Tem uma disciplina...

CS - Tem uma disciplina... Eu fico pensando assim, você não pode querer fazer teatro e ignorar tudo o que já fizeram: "eu vou começar do meu jeito e não quero saber!" Não pode! Nós bebemos dos nossos grandes mestres do teatro passado, que vai evoluindo... Daí entrou também esse treinamento da lben no LUME, que eu trazia para cá. Claro, que eu ensinava o Rique. Até passava para o Burnier e aqui a 
gente desenvolvia da nossa maneira, "vamos colocar isso, vamos colocar isso", a criatividade tinha que ser incluída. Não podia ser uma coisa morta nesse sentido. Então foi se desenvolvendo o treinamento do LUME. E foi crescendo... Depois que o Burnier morreu chegaram esses novos, ainda teve uma fase de se embrenhar no treinamento, mas era uma parte de 3 horas só, e as outras três horas era "o que é que a gente faz com isso? O que é que a gente cria? O que é que dá isso? Dá alguma cena? Dá alguma coisa? E se fizesse uma relação dos dois?" E a gente ia descobrindo tudo o que o treinamento nos dava para ir para o teatro. "Olhe que o treinamento será esse aqui. Vamos fazer juntos? Vamos ver no que é que dá?" Aí surgiam temas! Tanto é que o LUME nunca montou um espetáculo assim: "vamos montar Tchekhov!" Não, tudo era a partir do treinamento. Vinha uma inspiração e a gente ia por ali... "Ah, vou pegar por aqui". Como nós tínhamos o domínio da técnica, ela era sistematizada no LUME. Além de tudo por ser um grupo de pesquisa, não podia só pesquisar por pesquisar. Você tinha que sistematizar aquilo que você encontrava, "metodologizar", edificar, porque era uma universidade, né? Você tinha que ter algo concreto. E nós éramos muito fortes nisso. Surgiam coisas, a gente "metodologizava", sistematizava e ficava com a gente. la crescendo, sabe? la agregando. E os espetáculos eram sempre resultados desses treinamentos. Por quê? Porque se o treinamento significasse só o treinamento, seria um saco! Como é que ele ia mudando? Por exemplo: foi comigo a primeira vez: eu odiava treinar, chegou um momento que eu não queria treinar, não queria mais fazer nada!
MT - ... uma estafa?

CS - Nem é estafa. Não tinha vontade de ir lá, de fazer o que eu já vinha fazendo a 12, 13 anos, a mesma coisa, você entende? Eu não vou, não vou! Aí comecei a inventar: "ai, tô gripado hoje"; "destendi a perna"... Aí eu pensei: não, Simioni, para! Se você não está gostando é porque alguma coisa está dizendo "não é mais por aqui". E aí foi um dos grandes saltos, tipo assim: como é que a gente transforma? Não quero mais fazer esse treinamento, não quero mais fazer esse treinamento energético. Que é a tal da exaustão que todo mundo fala, mas que não é exaustão, é treinamento energético que te leva a algo... É aí que comecei a pensar: será que eu preciso passar pela exaustão para chegar ao estado que chego depois das três horas? Não, eu percebi que o treinamento já me deu isso. Era só eu acionar!

MT - Porém, eu entendo que você só chega a ter esta postura, devido a uma longa trajetória anterior de treinamento, certo? Uma vez que a técnica já está no seu corpo, não precisa você ficar mais tantas horas treinando.

CS - Sim! Mas esse é o LUME! Esse é a maneira do LUME. A maneira do LUME de você sempre transformar. Eu vejo a Iben, são 27 anos de "Ponte dos Ventos"! Desde quando a gente foi a primeira vez, há 27 anos, o treinamento é o mesmo! Então, olha só, existem várias vertentes, a minha sorte é que eu estou nessas duas. Afinal, o que é mesmo treinamento? É uma sequência. Claro que demorou, mas virou uma sequência que começa com a Dança dos Ventos, depois vai para o Verde, depois para o Samurai, depois para o Slow Motion, que é o boneco, e depois vai para fora do equilíbrio, e acaba. Há 27 anos, com a Iben, eu faço Samurai. O mesmo Samurai, certo? Mas olha só 
o que é que acontece: por ser repetitivo, por você ter que fazer a mesma coisa por 27 anos, você resolve com você mesmo mudar a maneira como você faz esse treinamento. Eu não vou mais descobrir mais coisas como já descobri há 20 anos atrás. O que é fazer um Samurai? O que é que ele me dá? etc... O quê vai transformando é a maneira como eu me coloco para fazer Samurai hoje, entende? O que é que o Samurai me deu como força para eu ir além mesmo dentro do Samurai?

MT - ...eu vejo que o treinamento é o mesmo mas você mudou. O seu corpo muda todos os dias...

CS - ...eu mudo. Isso que é fantástico para o ator. Acho que o treinamento é fantástico para o ator, porque o treinamento é um cárcere. É uma prisão. Tanto é que tenho o espetáculo "a prisão para a liberdade". Eu acho que se você se enterrar no treinamento é uma grande prisão. Se o ator ficar ali, só ali, ele está condenado.

MT - Acredito que é importante ressaltar o perigo dessa prisão. É necessário o ator saber deste risco e perceber a necessidade de sair deste lugar para fazer o seu corpo expandir de fato, estou certo?

CS - Exato! É necessário! E você só vai descobrir que você está prisioneiro, quando você já está prisioneiro, para você sair daquilo. Quando você sai você descobre um paraíso. Eu estou nessa fase. Já faz 10 anos que eu estou nessa fase. Só para dar uma luzinha a respeito, por exemplo, o próprio Odin, eles pararam de treinar! Eles não treinam há muitos anos. Quando eu conheci a Iben, já há 28 anos atrás, eles já não treinavam, então eles treinaram só até os 20 anos de grupo. Uma coisa assim. Aí cada ator tem o seu próprio treino que eles transformaram em cursos, fixado, é aquilo ali e tudo mais. Justamente é aquilo que eu falei na lben, até hoje o treinamento é o mesmo! O Odin tem isso. Vai fazer um curso com a Roberta e está tudo codificado. Não posso dizer porque não fiz. Mas pelo que me falam é codificado, é aquilo ali, e é a maneira como eles encontraram de transmitir algo para o ator. Como forma de treinamento que esse ator pudesse usar como um trampolim, para ir embora, para brincar, para explodir e para ser, você entende? Olha, vou para o Odin sempre. Conheço muita gente que pega o treinamento e, passa boi e passa boiada, passa ano e passa ano, e está consolidado numa forma, está prisioneiro, sem vida e tudo o mais. Tem gente que segue e vai, mas o que sinto da parte deles, quando eles mostram uma coisa fixa, é para que isso seja uma âncora para que você possa voar e voltar.

MT - Mas será que a potência deste treinamento dependente daquele contexto em ele foi desenvolvido pelo Odin, ou seja, será que nos dias de hoje estes procedimentos ainda funcionariam?

CS - Independe. Eu acho que o ator tem que entrar neste estado para que saia dele mesmo, para que ele possa criar. Mas também depende de que tipo de ator você quer ser! Tem milhões de possibilidades e tem várias vertentes, várias vertentes! É lógico que se um ator escolhe esse tipo de teatro é porque ele está interessado justamente em ir além... Numa entrevista que fiz com a Iben, eu perguntei: "Iben, quando você vai montar um espetáculo, como que você cria? Você pega as coisas do treinamento?" Ela falou: "Não, eu nem penso no treinamento! Para mim, é quando vem o figurino. 
Depois do figurino vem o personagem, aí eu faço". Só que, não sei se você já viu a lben em cena, tudo que o treinamento deu para ela está no corpo dela! Ela não precisa nem pensar, vem o figurino e quando ela vai se movimentar nesse figurino vem tudo que ela desenvolveu no treinamento, no corpo dela. Tudo que ela é. O que que é o treinamento? É unicamente uma maneira de você poder ultrapassar fronteiras, sair da sua mesmice. Por mais que o treinamento faz você ser o mesmo, faz você ser a mesma coisa em matéria de treinamento. Mas é justamente isso para você se ver: "nossa, meu corpo está fechado nisso daqui, como que eu rompo com isso?". Tipo assim: Como que eu posso dançar sem pensar no treinamento mas o treinamento está por trás do que me deu tudo isso. Então frisando: o treinar por treinar é educação física. Só. É isso.

MT - O que você pode me falar sobre esses três termos: pré-expressividade, organicidade e treinamento do ator?

CS - É tudo igual (risos). Eu acabei de falar tudo isso. Eu acho que a pré-expressividade é isso que eu acabei de falar da Iben. Ela tem o treinamento dela de acionar expressão, acionar momentos, acionar emoção, acionar corporeidade, que o treinamento é a pré-expressividade que está ali latente. Ela trabalhou para isso o tempo todo. Organicidade para mim é o teu corpo. Só que ali você está se forçando a dar mais do que você dá no momento, do que no teu cotidiano. Quando você está num treinamento energético onde a tua pulsação acelera, onde tuas emoções explodem, onde você faz gestos que nunca fez, mas você está ligado em você, dentro de você mesmo, porque você está acionando toda essa pré-expressividade, todas essas coisas, não tem como não ser orgânico! Dentro de mim tem um pulsar de vida tão forte, tão forte que através da prisão, através da técnica, eu criei esse pulsar que me leva a fazer as coisas. Eu não saberia encontrar esse pulsar no meu cotidiano, esse pulsar orgânico. E o treinamento do ator do ator é tudo isso. E a técnica vem para emoldurar. Sabe uma moldura de um quadro? A técnica é uma moldura, você só tem que encontrar formas para colocar essa organicidade, este leão você acorda, numa técnica, numa maneira de fazer com o corpo.

MT - Quais são os principais pilares do seu treinamento? Como essas práticas vêm se modificando ao longo dos anos desde que você começou?

CS - Como já disse, ele vai se modificando. Por exemplo: para pegar esse estágio que você está presenciando aqui no APA, o Portal e tudo o mais. O Portal surgiu, para mim, de maneira bruta, há 12 anos. O que significa: meu treinamento até então, todo energético, a Dança do Ventos, o de Mímesis, o de clown, os treinamentos em si, me levaram a um lugar que eu sempre chegava naquele estado. Era um estado quase que de iluminação. Eu digo isso porque tanto eu sentia quanto as pessoas que viam: "Nossa Simioni!" É um estado que ...sei lá... é muito forte! Eu sentia isso. Até eu pensei assim: "O que é isso? E o que eu posso fazer com isso?" Foi daí onde eu comecei a pensar: Como eu tenho a minha bagagem de 15 ou 20 anos de sistematização de técnicas, de descobertas e invenção de tipos de treinamentos, eu comecei a descer... eu estava naquele estado iluminado, por assim dizer. lluminado não é a palavra certa, mas um estado que você vê quando as pessoas chegam no Portal. Sabe aquele estado de presença, de beleza... Então 
eu comecei a descer assim, sabe? Como consigo encontrar uma maneira para que os atores cheguem nesse estado sem passar pelos 15, 18 anos que eu fiz? Demorou anos para eu inventar. Daí surgiram as 4 Camadas. Assim, eu preciso dar para os atores o que eu tive, que foi pauleira de treinamento energético, de cansaço, de trabalhar com o corpo doendo e tudo mais. Ali não, quando você vai para a $4^{a}$ Camada. Você vê que tem aquele esforço, tem que carregar teu corpo. Diferente do Portal. Quando o ator vivenciou este aprisionamento muscular, passo para a $2^{a}$ fase, que é a de entrar no Portal. Aí, mergulhando no corpo dele, tão devagar, mas sempre em cima de regras, de disciplinas, é a $1^{\text {a }}$ Camada, é a $2^{\text {a }}$ Camada, assim eu coloco ele numa prisão, você entende? Agora, para entrar no portal, vai devagar na $1^{\text {a }}$ camada. Chega na primeira camada. Você solta nesse estado sublime que estava lá em cima quando começou. Então vou fazendo uma ponte. O que é isso? Então, se o meu treinamento mudou? Mudou muito, mudou muito muito muito muito muito! Mas para meIhor! Porque agora eu consigo alcançar estados mais altos de ser, e com uma metodologia, uma técnica que funciona para outros atores que eles não precisam passar dez anos, que funciona. Eu sempre tive essa preocupação de que técnica pela técnica não serve para nada. O Portal é justamente esse entrar no coração, no seu ser. E de você ampliar tuas percepções, tuas imagens, tudo isso. O Portal é isso, é tudo, todos os presentes que vêm. Então, meu treinamento muda e espero que mude bastante. Agora ainda mais, agora estou com Stephane, então ele está mudando mais ainda meu treinamento. A maneira como ensino. Então foi justamente a ideia que tive assim: "Ah, por que não agora elaborar, vir um treinamento que não seja uma pessoa do LUME?" Porque sempre as pesquisas que eu fiz, pesquisas de verdade de encontros de treinamentos e tudo o mais eram com os atores do LUME. Era nós.

MT - ... com a galera já treinada , já preparada...

CS: Agora de repente eu estou junto com outro camarada que também tem um trabalho tão forte, mas que segue uma linha diferente. Isso para mim é maravilhoso! Como você falou, sei lá, estou espalhando sementes, e o Stephane construindo. Eu jogo alguma coisa etérea e ele vai construindo. Isso para mim é fantástico, ele vai desenhando e pensando no ator.

MT - Você acha que esse exercício que você criou do Portal é realmente equivalente a todos esses 15 anos de trabalho?

CS - Sim, sim.

MT - Neste sentido, a impressão que tenho é que da mesma forma que a Iben coloca um vestido e em seu corpo já vem todo o seu treinamento implícito, você se veste do Portal. Estou certo?

CS - Bravo! Bravo! Sim! Mas estou descobrindo uma coisa que também é fantástica, mas eu posso falar pouco sobre isso, que é aqui no A.P.A. que estou descobrindo. O que meu trabalho desses anos todos me deu, todo esse treinamento, lembre-se que eu saí desse treinamento, sempre fui trampolim, fui além, sempre além, de descobrir que através disso, a maravilha que é o trabalho do ator e do "ser ator" no sentido da dilatação e do estado de presença como você está vendo! No Portal, por exemplo, ele amplia de uma tal forma a sua consciência, não só a consciência daqui mas a consciência do todo, que você, quando recebe 
um presente, por exemplo, nada mais do que você ampliado! Você com a percepção mais aguçada. E isso é fantástico com o ator porque abre um lugar para o ator, porque é o trabalho dele. Então ele colhe, ele tem capacidade de ler a ele mesmo com mais vivacidade, com mais percepção. $O$ treinamento é todas essas coisas que só faz aflorar... É, então é isso.

MT - Como você relaciona a escolha estética com o treinamento que vem sendo desenvolvido? E como funciona a relação treinamento/ dramaturgia em seu trabalho?

CS - É... por exemplo, agora já não ligo mais para treinamento e dramaturgia. Eu não pego nada do treinamento para criar meu trabalho. Mas no começo o "Kelbilin" há quase 30 anos, era do treinamento que descobri a Dança Pessoal. O treinamento que deu todas as ações do "Kelbilin" e o Burnier só ajudou e criou o espetáculo. O do palhaço, também, era toda a mecanicidade do palhaço, a estrutura do paIhaço, que não era a nossa, já existia a maneira de ser do palhaço, do circo e tudo mais, mas com minha técnica, com minha expressão. Só que daí, o que fazia falta para um clown? Era se relacionar com o público! Então o Burnier fazia eu e o Rique ir para a rua de clown, sem "sketch", sem nada preparado, só para ver como que a gente reagia com o público. Público não, as pessoas me davam alguma coisa para eu reagir, para eu descobrir mais maneiras para meu clown. Depois dessa relação, a gente levava para sala e fazia a relação entre ele, eu e o Burnier e com esse trabalho construíamos um espetáculo. A Mímesis, "Café com Queijo", também era a mesma coisa. Era o treinamento de Mímesis. Eles foram para lá, copiaram, voltaram para a sala de trabalho. Só que agora vai mudando, por exemplo: "Sopro", o meu espe- táculo, o último solo, "Sopro", é justamente desse momento onde eu descobri uma iluminação. "lluminação" talvez não seja a palavra mais adequada. Escolhi. Cheguei num lugar que eu nunca tinha chegado, aí eu disse: "eu quero criar um espetáculo sobre isso". Deste estado, criei o "Sopro". Chamei um diretor de fora, para me ajudar e tudo mais, o Tadashi ${ }^{4}$. Então meu treinamento vai modificando, e a relação com a dramaturgia nunca existiu, no máximo um tema. Mas que também deve ser maravilhoso trabalhar com texto, né? É preciso. Eu não tive vontade ainda, mas um dia eu vou fazer, um dia eu vou fazer...

MT - E no seu trabalho pessoal, você ainda executa alguns exercícios específicos relacionados à exaustão, como a Dança dos Ventos, elementos plásticos e Pantera?

CS - Não. Não faço mais isso. Claro, que eu faço para ensinar, não é? Você está vendo, estou lá e estou dançando a Dança dos Ventos. Mas não, porque já não precisa mais. A Dança dos Ventos já me deu o lugar. A Pantera já me deu o lugar. Os elementos plásticos já me deram o lugar, já cheguei num lugar que saí deles, mas por causa deles.

MT - Durante sua pesquisa, você encontrou alternativas equivalentes que possam substituir as qualidades alcançadas pela a exaustão?

CS - Não sei, eu não posso dizer, sabe por quê? Porque aqui a palavra como vocês falam "exaustão", dá uma coisa assim, "exaustão, então tudo se pode fazer para se exaurir". É muito fechado "exaustão", né?

4 Tadashi Endo, além de diretor e bailarino é um dos mestres da técnica do Butoh. 
MT - ... como, por exemplo, você encontrou um caminho para o Portal sem ter a necessidade de passar 15 anos treinando, sem passar pela exaustão.

CS - Sim, sem passar pela exaustão. Mas o que a exaustão me deu, eu sei do meu corpo, o que é preciso fazer para ensinar aos alunos sem a exaustão. Um dos exemplos é a $4^{\text {a }} \mathrm{Ca}$ mada. A $4^{a}$ Camada, se você ficar mais que uns dez minutos você começa a suar, mais que dez minutos...

\section{MT - E é necessário?}

CS - É necessário. Dez minutos são necessários... Mas isso é o que eu digo, não lembro em nenhuma vez na minha existência de LUME que eu ia treinar e pensava: "preciso chegar à exaustão". Nunca existiu isso, aqui que é o problema. Chegar a exaustão não era a meta, não era o ponto final chegar na exaustão. Qual é a graça? Nenhuma. Por isso que existe um grande equívoco quando ouço isso de "chegar a exaustão", mas por quê? Eu acho que é o exaurir-se que te dá trampolim para você ir além. É só isso, mas não é objetivo chegar a exaustão. Por exemplo, quando eu te dou a $4{ }^{\text {a }}$ Camada, ela espreme de tal jeito que você, no lugar de chegar a exaustão, de ficar acabado, etc., justamente essa efervescência do exaurir-se, do ir além, acontece na $4^{\text {a }}$ Camada, porque é um esforço muito grande, mas eu já deixo para explodir! Quando falo "depois da $4^{a}$ camada" e quando falo "quero ir", só mandar "quero ir", mas não vou com o corpo, "quero ir para a $4^{\text {a }}$ camada", o que é? É o resultado do treinamento energético. Quando você vai além, você tem a capacidade de acionar o seu corpo com uma coisa, uma qualidade de energia que vai além do que você é. Mas que você controla que você está dominando. Você sabe porque você chegou ali. Você alavancou. Você foi. Eu entendo que não preciso passar pela exaustão. É mas um esforço do que a "exaustão". É lógico que é um esforço imenso ficar fazendo elementos plásticos por duas horas. É um esforço imenso mas eu nunca pensei em exaustão. Nunca.

MT - Como lidar com a sua espontaneidade diante das "rígidas" técnicas que já vinham sendo trabalhadas?

CS - Como lidar com a sua espontaneidade? Quando se fala "rígidas", vocês estão tentando me enganar, dizendo que o treinamento é uma coisa rígida, fechada, é uma exaustão e não é! Eu não vejo assim, você entende? Não seria a palavra rigidez.

MT - Eu entendo, quando falo a palavra "rígida" me refiro às especificidades e às precisões que são necessárias para executar diversas técnicas.

CS - Na realidade, a pergunta aqui eu responderia assim: é ... como todas as nossas técnicas de LUME, elas tinham essa tal de rigidez que vocês falam, essa precisão, esse cuidado com a técnica. Porque se você faz o Samurai, por exemplo, é para te dar algo e não é só para fazer Samurai. Todas aquelas regras rígidas do samurai é para que você encontre no seu corpo um mecanismo orgânico que você obtenha uma energia que seja uma energia dura, de rocha, uma energia que não se espaIha, uma energia condensada. Isso para o ator é fantástico. O Samurai, essa prisão, é para isso, para que quando você se livrar do Samurai e da técnica rígida, você vai ver o que ela te deu. Ponto. O clown, por exemplo, quando você joga o clown dentro do teu corpo, aí é que está: a gente nunca joga o clown dentro 
das técnicas rígidas, você entende? Por que as técnicas já estavam implícitas. As técnicas servem para transferir o ator para uma outra coisa e não para ficar na técnica. Para transformar num trampolim, a explosão. Aí quando o clown entra, ele não entra debaixo da rigidez se não ele não seria espontâneo. Ele entra nesse lugar que o ator descobriu. Que é essa plenitude... esse estado.

MT - Ao codificar e repetir uma plasticidade alcançada em laboratório, seja para um espetáculo ou para uma demonstração rápida, a potência corporal alcançada outrora é comprometida?

CS - Ela tem um momento que se esvai. Quando você está tentando codificar a repetição, ela vai perdendo o frescor. Bem, ela vai perdendo o frescor porque você precisa mecanizar. Você precisa pensar "não, aqui tem que fazer isso, aqui eu tenho que fazer isso", eu tenho que repetir. Está marcada essa cena, essa ação, essa cena que eu quero fazer tem que repetir. Ela vai ficando sem graça para o ator e para quem assiste, para quem está vendo. Agora, ele precisa passar por isso, porque até que o corpo dele diga "ok, já está codificado, já repeti bastante, já estou seguro nisso, não preciso mais pensar nisso, vou colocar o meu ser nessa repetição, nessa codificação" e aí de novo aquilo que tava enfraquecendo etc., ela sobe e você domina o que você trabalhou. Você não muda nada.

MT - Você vê alguma relação entre essas técnicas de exaustão, com as posteriores lesões (dores no joelho, na cervical etc.) identificadas em alguns atores ?

CS - Não é técnica de exaustão. Que fique bem claro isso, né? (risos)... aqui já fala "em alguns atores". Se fosse em todos, aí eu ia di- zer "realmente essa técnica está danificando todo mundo". Então, não tem. Eu, por exemplo, faço isso há 32 anos, estou com 57 anos e não tenho nada quebrado. Nada danificado. Nada! Ainda por cima ainda dei um rim para minha irmã, estou sem um rim. Não vejo nada disso nos colegas todos que fazem isso. Não vejo nada disso. A própria lben, que ela não trabalha com treinamento, mas o espetáculo dela, se você for ver, é um treinamento! Chega a dar medo, porque ela voa para cima e para baixo, e ela tem 72 anos, você entende? O máximo que pode ser é a velhice. É natural. No caso dela, 72, e eu mesmo 57, eu já penso: "tem coisas que já está difícil para eu fazer". Mas isso é porque eu fazia, faço coisas que fazia com 20 anos. Olha a diferença de corpo. Agora de dançar, cantar, isso acontece com gente que faz errado, talvez, ou às vezes gente que têm problemas. As vezes são pessoas que já têm problemas físicos e vão fazer isso e se machucam. Mas eu não vejo! Então a resposta é "não", neste sentido. Porque é diferente se você pega, por exemplo: um bailarino clássico. Esse sim, coitado, ele se deforma, ele usa o corpo dele de uma forma tão exagerada, que ele só pode dançar até seus 20 ou 35 anos, no máximo... não sei, salvo alguma exceção. O corpo se desgasta. Conheço bastante bailarinos que têm problemas na coluna...

MT - ...e não há esse desgaste nesse treinamento do ator?

CS - Não. Não há desgaste, não tem. No caso do bailarino clássico, ele vai fazer a mesma coisa por 20 anos, a mesma... é ali, naquela postura. E no caso do ator, não. O ator é justamente isso, ele é muito livre. Apesar da prisão ele encontra liberdades! E por exemplo: quando você vai fazer um treinamento que é 
um Samurai, por exemplo, a Dança dos Ventos, quando eu faço ali, para mim é uma liberdade tão grande fazer a Dança dos Ventos, tão grande, que eu não sinto nada no corpo. Dói depois, assim, dores musculares, como qualquer um.

MT - Você acha que esse tipo de treinamento ainda tem a mesma importância para o jovem ator de hoje? Se não, o que mudou? O que se mantém? Rigor, disciplina, princípios, espírito de grupo?

CS - Claro. Mas eu ainda insisto: não é o único meio de se trabalhar o ator. Não é, existem miIhões de outras formas. Isso é para quem quer fazer esse tipo de teatro. Por exemplo: as performances que eu sinto hoje. O que é performance? Aí as pessoas perguntam "para que treinar? Porque eu não preciso, tenho que ser natural etc.". Eu concordo, porque a performance tem uma outra coisa. No teatro, é só o ator que está ali, entende? Tem o figurino, o texto, mas é a presença do ator e tudo o mais. A performance se escora, no bom sentido, de muitos subterfúgios, sabe? Por exemplo, tem performance que é: "ela" costura fitinhas no corpo. Então ela nem precisa ter presença, porque aquela situação já é impactante. Então estou dizendo isso para quem escolhe esse tipo mas há outro tipo de atores que não... O rigor ficou porque ele faz parte de você. Você não vai fazer nada meia boca, né? Eu vou ser rigoroso comigo! Eu sei que se eu me empenhar $100 \%$ no meu bem fazer quem ganha sou eu! Então eu não vou me enganar, tipo "ah...eu não vou ser tão rigoroso aqui”... Isso o treinamento te dá. Mas não que "rigoroso", a palavra também é horrível, né? “Tudo que eu faço é rigoroso!" Não. O rigor é no sentido de eu ser honesto comigo mesmo. No meu treinamento, não vou pular etapas.
MT - Como você vê o teatro hoje, contaminado pela performance, pela não-representação, uso de não-atores e uso do real em cena?

CS - Eu acho normal... eu não gosto. Eu não gosto de ir ao teatro para ver isso. Mas já vi.... Às vezes tenho que ver por causa de amigos. Eu acho assim: "ah, que legal, ele tá feliz fazendo isso", entende? Eu olho para o público do lado, está todo mundo gostando, adorando, só eu que não gosto, mas se está funcionando com o público.

MT - Você acha que essas novas tendências podem de alguma forma anular o teatro que já vinha sendo desenvolvido?

CS - Eu acho até bom. Eu acho até bom porque sai para descobrir outras coisas. No teatro sempre foi isso. Essas performances extrapolam vai, vai, não tem regras, não tem nada. É uma felicidade a possibilidade de você expressar de sua maneira. Não através de um autor, através de uma estrutura teatral etc., eu acho isso muito bom para o ator, ele cresce.

MT - São elementos que poderiam entrar no próprio treinamento, certo?

CS - Com certeza. Mas não significa que eu tenha que odiar o teatro porque agora eu faço performance. Não, não significa isso. Você está com uma outra linguagem.

MT - O que lhe inspira no teatro hoje ?

CS - O que me inspira no teatro hoje...? Para mim, no teatro hoje, o que me inspira é justamente essa possibilidade de o ser humano mostrar a sua beleza total. A gente subjuga o ser humano, porque a gente é só isso. O ser humano é isso. Tem que se encaixar na casinha. O teatro tira esse ser humano da casinha. Coloca-o num lugar ampliado de percepções, 
de emoções e amplitude e sempre você vê a beleza do ser humano, mesmo que ele seja ruim, ou mesmo que ele seja mau, mas dentro da expressividade do ser humano ele pode ser belo. Ser humano é belo. O que eu vejo que me inspira para fazer teatro hoje é de colocar o ser humano no seu real valor, que é uma beleza, a potência. Muito mais do que a gente está acostumado, do que a gente aceita.

MT: Valeu, Simi!

Recebido em 16/12/2016 Aprovado em 26/12/2016 